\title{
Strontium isotopes and crustal evolution
}

\section{from J. Sutton}

ONE of the most intriguing problems in geology at the present time is the investigation of the first 2,000 million years of the Earth's history. We have now a detailed knowledge of small areas of crust dating from the latter part of the first 1,000 million years of geological time. But the remnants of crust formed more than 3,500 million years ago are no more than a few tens of kilometres across at the most and are widely separated from one another.

What we badly need is information on large scale activities within the primitive Earth, for this might link our fragmentary scraps of knowledge obtained from the ancient rocks exposed in Minnesota, west Greenland, southern Africa and Antarctica.

Moorbath's paper in this issue of Nature (page 395) provides just such information, for the strontium isotope studies he reports here and those which Moorbath, Powell and Taylor have reported elsewhere (J. geol. Soc. Lond., 131, 213; 1975) bear directly on the question of the movement of material between crust and mantle in Precambrian times. Moorbath reports very low ${ }^{87} \mathrm{Sr} /{ }^{86} \mathrm{Sr}$ ratios in the crustal rocks he and his colleagues have investigated and deduces that the rocks in question had formed from material which had been transferred to the crust from the mantle shortly before the times when they last crystallised. $\mathrm{He}$ is in effect employing ${ }^{87} \mathrm{Sr}$ as a natural radioactive tracer to follow the circulation of silicates in Precambrian times. This is now a well established technique but Moorbath's application of the method to the very old (roughly 3,700-3,600 Myr) rocks of Greenland and Rhodesia has produced results of great importance for our understanding of the early Precambrian.

The use of strontium isotopes in this way is in itself a faseinating concept. Since the time the Solar System formed, ${ }^{87} \mathrm{Sr}$ has increased in abundance as ${ }^{87} \mathrm{Rb}$ breaks down, the rate of increase in any rock being governed by the amount of rubidium present. The distribution of strontium isotopes through the Earth is therefore influenced by the manner in which rubidium and strontium are associated in rocks. Since rubidium can be admitted to $\mathrm{K}^{+}$sites in the main rock-forming potassiumbearing minerals it is widely distributed as a trace element in the potassiumrich granitic rocks abundant in the upper crust but is much less abundant in the potassium-poor basic and ultrabasic rocks of the lower crust and mantle. Study of the ratio ${ }^{87} \mathrm{Sr} /{ }^{x 6} \mathrm{Sr}$ can provide critical information as to the origin of an igneous rock. A melt derived from the mantle will be marked by relatively low initial ratios of ${ }^{87} \mathrm{Sr} /$ ${ }^{86} \mathrm{Sr}(0.699$ from 4,600 million years ago to about 0.704 at the present day). In contrast in continental crust rubidium-rich granite can accumulate ${ }^{x 7} \mathrm{Sr}$ much more rapidly as the figures illustrating Moorbath's article indicate. Accordingly a melt derived from granites which have resided for long periods of geological time in the crust may inherit this high ratio as an initial feature and so be distinguished from rock derived directly from the mantle. Moorbath has been able to show that the initial ${ }^{87} \mathrm{Sr} /{ }^{86} \mathrm{Sr}$ ratios of the 3,700-3,600 million years old Greenland and Rhodesian rocks are so low as to suggest derivation directly from the mantle of those times. $\mathrm{He}$ has also found, as have earlier investigators of rocks formed rather later in the Precambrian, that rocks developed between 2,800 and 2,500 million years ago are marked by low ${ }^{87} \mathrm{Sr} /{ }^{86} \mathrm{Sr}$ ratios. These are close to, or at most a little above, values expected of the mantle at that stage in the Earth's history.

Moorbath concludes that these younger Precambrian rocks, some of which come from Scotland and Greenland, could not have been derived, as has been suggested, by the reworking of very much older granitic crustal rock such as the 3,700 million year old examples of west Greenland. Moorbath follows Hurley in concluding that these facts indicate a progressive addition of mantle material to the crust. $\mathrm{He}$ points out in the concluding paragraphs of his article that such transfers of material from mantle to crust seem to have been especially active at certain periods of time during geological history. Some of these periods, it may be noted, coincide with the abrupt changes in continental movement indicated by the hairpins in the apparent polar wander paths established by palaeomagnetic investigations.

One question raised by Moorbath's work with its additional evidence for a near identity of crustal and probable mantle ${ }^{87} \mathrm{Sr} /{ }^{86} \mathrm{Sr}$ ratios through early Precambrian time is of particular interest. Do these results indicate, as Armstrong has proposed, that matter was exchanged more effectively between mantle and crust during the first 2,000 million years? Perhaps at that time no extensive portions of the crust remained isolated for sufficiently long to establish ${ }^{87} \mathrm{Sr} /{ }^{\times 6} \mathrm{Sr}$ ratios significantly higher than those of the mantle.

\section{What came out of Kohoutek's comet?}

from J. F. James

A YEAR and a quarter have now passed since Kohoutek's comet passed perihelion with awful anticlimax and if we have learned nothing else, we are now warned once again of the danger of letting empiricism masquerade as science. With the nine months' warning of its approach there was ample time for elaborate international cooperation to be arranged and in spite of the disappointment of the amateurs and the disillusionment of the public the professional astronomers received it with a great broadside of astronomical equipment and studied it more comprehensively than any previous comet.

Many of the more important obser- vations have been reported in the December 1974 issue of Icarus (23, No. 4), which was especially dedicated to the comet, and the editors have promised more later on.

The discovery was made by $\mathrm{Dr}$ Lubos Kohoutek on March 21, 1973 and from three positions, one from a pre-discovery plate; Dr Brian Marsden published a preliminary orbit on March 26 (IAU Bulletin no. 2514). From its position and magnitude at the time of discovery and from an empirical formula used to predict the future brightness of comets, it was concluded by some astronomers that it would be very bright indeed at perihelion and would become even brighter later on as the tail developed. In fact it did get to magnitude -2.3 at perihelion and was observed at the time by the crew of Skylab IV, 200 miles above grcund. It was of course invisible at ground level because of the glare of sunlight.

Curiously there was no elaborate series of observations from Skylab IV and the observers there used the archaic method of making drawings of the appearance of the comet. These drawings were sent down to Earth by television link. Skylab's crew were the first to cbserve the tail of the comet and also found the 'anti-tail', a sunward-pointing spike like that of the Arend-Roland comet of 1956. As the 